\title{
Problems of doctor-patient communication in medical practice. Ways to approach the patient in complicated cases
}

\author{
Problematica comunicării medic-pacient în practica medicală. Modalităţi de \\ abordare a pacientului în cazurile complicate
}

\author{
Ana Maria Alexandra Stănescu', Ioana Veronica Grajdeanu', Ovidiu Gabriel Bratu ${ }^{1,4,5}$, \\ Cristina Olariu ${ }^{1,6}$, Mihaela Adela Iancu ${ }^{1}$, Ioana Florentina Codreanu ${ }^{1,2}$, \\ Camelia Cristina Diaconu ${ }^{1,3}$ \\ ${ }^{1}$ Universitatea de Medicină şi Farmacie „Carol Davila“, Bucureşti, România \\ 2INSMC „Alessandrescu-Rusescu“, Bucureşti, România \\ ${ }^{3}$ Spitalul Clinic de Urgenţă, Bucureşti, România \\ 4Spitalul Universitar de Urgenţă Militar Central „Dr. Carol Davila“, Bucureşti, România \\ ${ }^{5}$ Academia Oamenilor de Ştiință din România \\ ${ }^{6}$ Institutul Naţional de Boli Infecţioase „Prof. Dr. Matei Balş“, Bucureşti, România
}

\begin{abstract}
Currently, the physician-patient relationship is a bidirectional one, the center of which is communication. Communication is no longer regarded as an option but as a necessity in the day-to-day practice of physi-cians. The way we use communication can make a big difference on the physician-patient relationship, on the understanding of the disease, the treatment, and on the subsequent conduct of the patient. The approach to this subject comes in the absence of formal courses for doctors in communication, a necessary and beneficial thing both for the doctor and for the patient.
\end{abstract}

Keywords: communication, doctor, patient

\section{REZUMAT}

La ora actuală, relaţia medic-pacient este una bidirecţională, în centrul căreia se află comunicarea. Comunicarea nu mai este privită ca fiind o opţiune, ci ca un necesar în practica de zi cu zi a medicilor. Modalitatea în care folosim comunicarea poate face o mare diferenţă asupra relaţiei medic-pacient, asupra înţelegerii bolii, tratamentului şi asupra conduitei ulterioare a pacientului. Abordarea acestui subiect vine în lipsa cursurilor de formare pentru medici în ceea ce priveşte comunicarea, un lucru necesar şi benefic atât medicului, cât şi pacientului.

Cuvinte cheie: comunicare, medic, pacient

\section{INTRODUCERE}

\section{Comunicarea în medicină}

Este bine cunoscut faptul că pacientul este expus la stres şi cu cât este mai mare gravitatea afecțiunii pe care o are, cu atât stresul este mai intens. În cazul bolilor cronice, stresul devine permanent pentru aceşti pacienți, fie că realizează sau nu realizează acest fapt.

Stresul la care este expus pacientul a fost intens studiat, comunicarea medic - pacient devenind un factor extrem de important în practica de zi cu zi.

Comunicarea cu pacientul a ajuns la ora actuală să aibă aceeaşi importanţă ca punerea diagnosticu- 
lui corect sau instituirea terapiei corespunzătoare. De asemenea, aşa cum adaptăm terapia în funcție de pacient, este necesar să adaptăm şi modul de comunicare (1).

Pe de altă parte, mai puțin discutat este stresul zilnic la care este expus medicul, luând decizii cu referire la viața pacientului, fiind necesar să îi comunice acestuia starea de sănătate, terapia şi, nu de puține ori, veşti nu tocmai aşteptate de pacient (veşti negative) (2).

Persoanele cu probleme de vorbire, auz sau tulburări mintale necesită asistență specială în comunicare, în special în scopuri medicale (3).

Medicul se confruntă zilnic cu presiunea timpului, decizii conflictuale cu colegii, complexitatea cazuisticii, gestionarea propriilor emoții şi ale pacienților, stresul expunerii la suferință, la boală, la moarte.

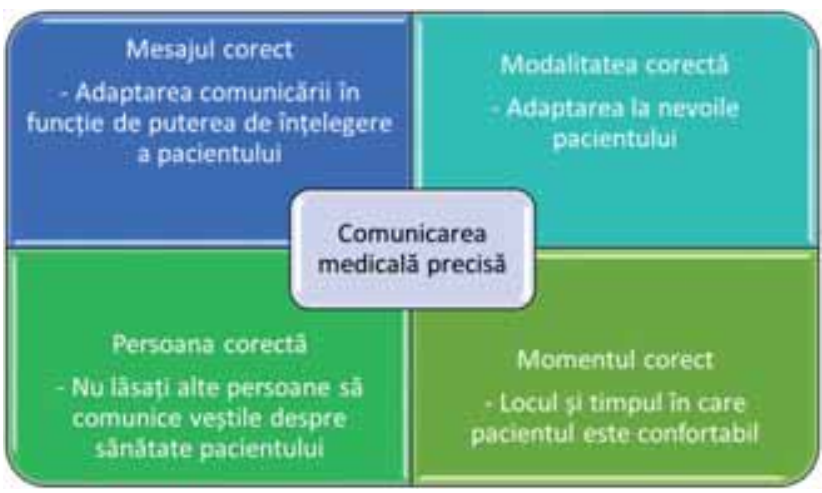

FIGURA 1. Factori ce influențează comunicarea medic-pacient (4)

Comunicarea suboptimală este cea mai mare sursă de eroare care poate fi prevenită în practica medicală (5).

\section{Problematica comunicării veştilor nefavorabile}

Vestea proastă poate fi definită ca ,orice informație care afectează negativ şi grav viziunea unui individ asupra viitorului său“"(6).

Comunicarea veştilor rele poate fi deosebit de stresantă atunci când medicul nu are experiență, pacientul este tânăr sau opțiunile terapeutice sunt puține cu o rată de succes scăzută (7).

Percepția pacientului dar şi a aparţinătorilor este în general însoțită de un şoc, mai ales în cazul cancerului.

În cazul cancerului, un studiu pe 1.251 de pacienți din anul 1982 arată că 96\% dintre pacienți doreau să li se spună dacă aveau diagnostic de cancer, iar $85 \%$ doreau să ştie prognosticul real al bolii şi cât mai aveau de trăit; un alt studiu mai recent efectuat pe 250 de pacienți din Scoția a arătat că $91 \%$ şi, respectiv, 94\% dintre pacienți au dorit să ştie şansele de vindecare a cancerului şi efectele secundare ale tratamentului $(8,9)$.

Modalitatea de transmitere a veştilor proaste poate influența gradul de înțelegere al pacientului, satisfacția față de actul medical, speranța, dar şi suportul psihologic necesar ulterior.

În urma studiilor, a fost descris efectul „MUM“, referitor la persoana care transmite veşti proaste: aceasta poate experimenta emoții puternice, cum sunt anxietatea, teama de evaluare negativă şi responsabilitatea asumării veştilor proaste (10).

Este necesară o instruire suplimentară a personalului medical, cu referire la modalitatea dezvăluirii informațiilor nefavorabile, această instruire fiind benefică atât pentru medic, cât şi pentru pacient.

Pregătirea mentală a medicului înaintea comunicării veştilor proaste este foarte importantă, me-
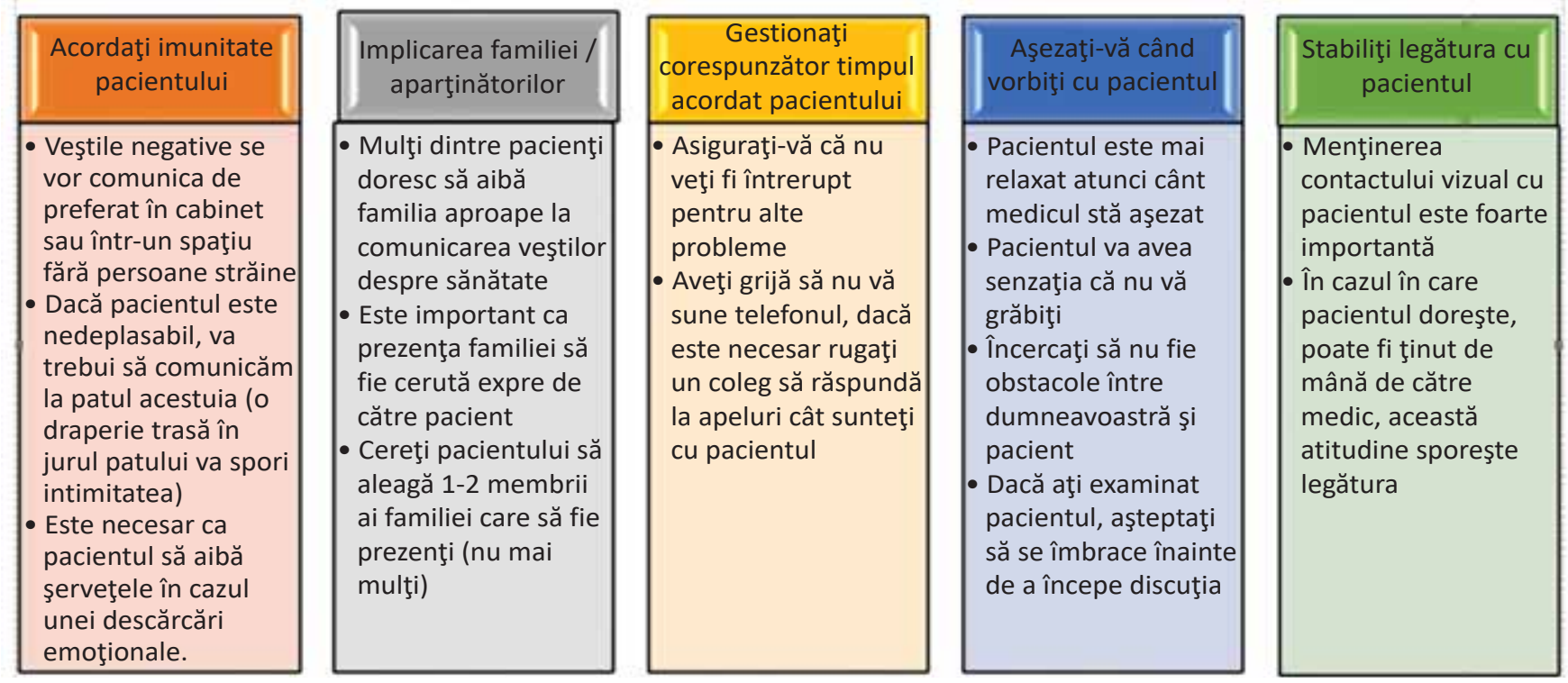

FIGURA 2. Pregătirea pentru comunicarea veştilor nefavorabile (11) 
dicul trebuie să ştie exact ceea ce doreşte să comunice pacientului, cum să răspundă la posibilele reacții emoționale ale acestuia şi să revizuiască posibilele întrebări ale pacientului.

Evaluați pacientul din punct de vedere al percepției sale. Începeți discuția prin întrebări adresate pacientului pentru a determina percepția pacientului asupra bolii, asupra gravităţii acesteia şi dacă există un anumit grad de negare. Întrebările vor fi centralizate pentru a afla ce informații are până acum despre starea lui actuală, dacă înțelege de ce a fost supus investigațiilor, dacă omite detalii importante ale bolii sau dacă are aşteptări nerealiste cu privire la tratament (12).

În continuare, pacientul poate exprima clar ceea ce doreşte să ştie sau să nu ştie despre starea lui de sănătate, sunt pacienți care vor dori să se focuseze pe tratament şi nu pe prognostic, complicații etc. Aceşti pacienţi vor trebui întrebaţi dacă au pe cineva în familie cu care medicul va putea discuta restul detaliilor (13).

Avertizarea pacientului despre vestea proastă care va urma poate diminua şocul acestuia. Informațiile medicale vor fi adaptate la nivelul de înțelegere al pacientului, în general, se vor înlocui, pe cât posibil, termenii medicali specifici cu un limbaj comun sau, atunci când nu este posibil, se vor explica termenii medicali pacientului. Informația trebuie dată gradual şi verificat dacă pacientul a înțeles mesajul.

Reacțiile pacienților sunt diferite - tăcere, plâns, negare sau furie -, fiind necesar ca medicul să dea dovadă de empatie.

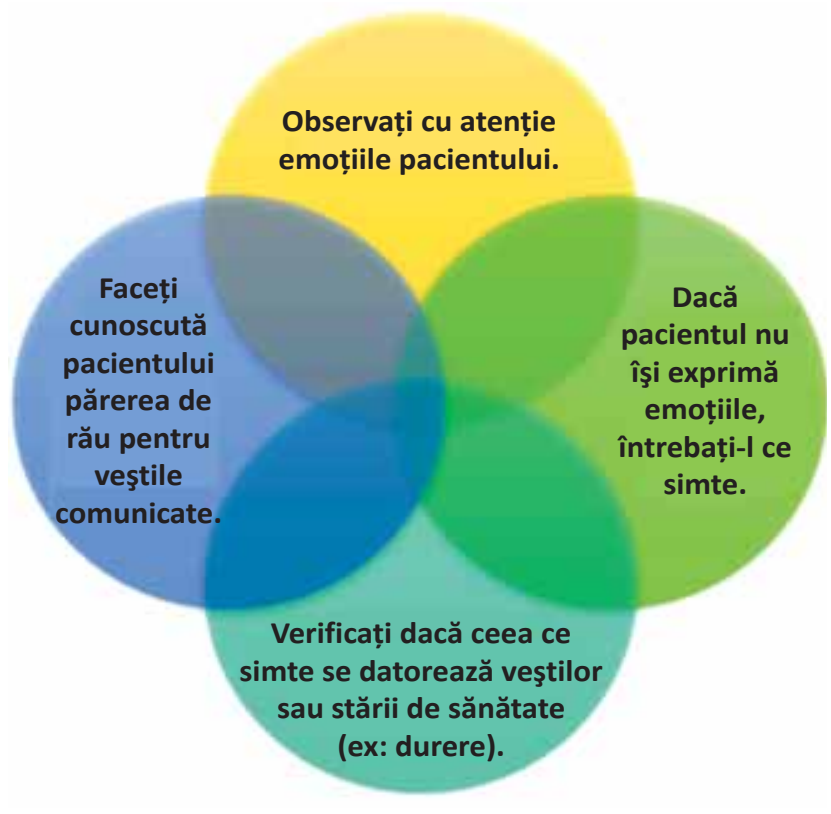

FIGURA 3. Observarea atentă a pacientului (11)
Pentru a evita ca pacientul să se izoleze, comunicați-i acestuia că sentimentele pe care le are sunt normale şi dați dovadă de empatie în continuare. Se va evita a se merge mai departe cu discuția până când pacientul nu îşi liniş̧teşte emoţiile.

În continuare, atenția pacientului trebuie îndreptată către planul terapeutic, atunci când există unul. Responsabilitatea tratamentului revine atât medicului, cât şi pacientului, acesta din urmă trebuie să înțeleagă atât beneficiile şi ținta terapeutică, cât şi toate riscurile, inclusiv rata de eşec.

Abordarea discuţiei prognosticului şi conduitei terapeutice, de cele mai multe ori, determină medicul la teama de a nu distruge speranța pacientului, incertitudine faţă de aşteptările pacientului, propria sa reacție la emoțiile pacientului.

În final, trebuie alocat timp suficient pacientului pentru a pune toate întrebările la care se gândeşte, apoi se va face programarea următorului control.

\section{DISCUŢII}

Lipsa cursurilor de formare în ceea ce priveşte comunicarea medic-pacient a dus la un impas din acest punct de vedere. Un studiu efectuat de Shea pe 2.516 oncologi a arătat că $40 \%$ dintre ei nu numai că nu aveau nici o pregătire în comunicare, dar nici nu au avut ocazia de a-i observa pe alți practicieni cu experiență în comunicarea veştilor negative (14).

Sunt necesare instruirea în comunicare încă din timpul facultăţii, pentru a avea timp să pună în practică cele învățate, şi, de asemenea, stabilirea unui ghid pentru eficacitatea comunicării în medicină (15).

\section{CONCLUZII}

Comunicarea în medicină reprezintă la ora actuală o provocare pentru medic, fiind absolut necesară în practica de zi cu zi. Cu cât este mai gravă afecțiunea pacientului şi cu cât este mai nefavorabil prognosticul, cu atât devine mai dificilă comunicarea. Ghidarea medicilor în astfel de situații poate fi de mare ajutor. Rămâne încă necesitatea cursurilor de specialitate în comunicarea medicală.

Conflict of interest: none declared Financial support: none declared 


\section{BIBLIOGRAFIE}

1. Per Vaglum. Rules of thumb - An educational tool in teaching clinical communication to medical students. Patient Education and Counseling, Volume 100, Issue 11, 2017, Pages 2151-2153,

2. Regina Katharina Studer, Brigitta Danuser, Patrick Gomez. Physicians' psychophysiological stress reaction in medical communication of bad news: A critical literature review, International Journal of Psychophysiology, Volume 120, 2017, Pages 14-22,

3. Krzysztof Wołk, Agnieszka Wołk, Wojciech Glinkowski. A Cross-Lingual Mobile Medical Communication System Prototype for Foreigners and Subjects with Speech, Hearing, and Mental Disabilities Based on Pictograms. Computational and Mathematical Methods in Medicine, vol. 2017, Article ID 4306416, 9 pages, 2017.

4. Rebecca Ashkenazy. Precision medical communication to optimize stakeholder information exchange: A '4M-Quadrant' approach. Drug Discovery Today, Volume 21, Issue 7, 2016, Pages 1039-1041,

5. Peter G. Brindley, Katherine E. Smith, Pierre Cardinal, Francois LeBlanc. Improving Medical Communication: Skills for a Complex (And Multilingual) Clinical World. Canadian Respiratory Journal, vol. 21, no. 2, pp. 89-91, 2014.

6. Buckman R. Breaking Bad News: A Guide for Health Care Professionals. Baltimore: Johns Hopkins University Press, 1992:15.

7. Ptacek J.T., Eberhardt T.L. Breaking bad news. A review of the literature. JAMA 1996; 276:496-502

8. Morris B., Abram C. Making Healthcare Decisions. The Ethical and Legal Implications of Informed Consent in the Practitioner-Patient
Relationship. Washington: United States Superintendent of Documents, 1982:119.

9. Meredith C., Symonds P., Webster L. et al. Information needs of cancer patients in West Scotland: Cross sectional survey of patients' views. BMJ 1996; 313:724-726.

10. Tesser A., Rosen S., Tesser M. On the reluctance to communicate undesirable messages (the MUM effect). A field study. Psychol Rep $1971 ; 29: 651-654$.

11. Walter F. Baile, Robert Buckman, Renato Lenzi, Gary Glober, Estela A. Beale, Andrzej P. Kudelka. SPIKES - A Six-Step Protocol for Delivering Bad News: Application to the Patient with Cancer. The Oncologist 2000; 5:302-311; doi:10.1634/theoncologist.5-4-302

12. Lubinsky M.S. Bearing bad news: Dealing with the mimics of denial. Genet Couns 1999; 3:5-12.

13. Gattellari M., Butow P.N., Tattersall M.H. et al. Misunderstanding in cancer patients: Why shoot the messenger. Ann Oncol 1999; 10:39-46.

14. Shea J.A., Frenkel E.P., Webster G.D. Training and practice activities of hematology and medical oncology diplomates. Arch Intern Med 1990; 150:145-148

15. Manyuk, L., Kuchumova N. Undergraduate Medical Communication Training by Means of Information and Communication Technologies in the USA and Ukraine. Comparative Professional Pedagogy, 2018. $8(1), 27-32$. 